\title{
The First Stable Platinum(II) Complex of o-Carborane-linked Bipyridine as a Potential BNCT Reagent
}

\author{
Jeongsoo Yoo and Youngkyu Do* \\ Department of Chemistry, School of Molecular Science-BK21 and Center for Molecular Design and Synthesis, \\ Korea Advanced Institute of Science and Technology, Daejeon 305-701, Korea. "E-mail: ykdo@ kaist.ac.kr \\ Received January 13, 2005
}

Key Words : Pt complex, Boron neutron capture therapy, Carborane, Cisplatin

1,2-Dicarba-closo-dodecaborane (o-carborane) is one of the most stable boron clusters. ${ }^{1}$ It is highly lipophilic, which is the required physical property in order to permeate cell membranes. Recently, a large number of compounds containing $o$-carborane have been prepared for their potential use in Boron Neutron Capture Therapy (BNCT). ${ }^{2}$ BNCT is a bimodal cancer treatment that is currently undergoing clinical trials in several countries. ${ }^{2}$ The therapy makes use of thermal neutrons of low kinetic energy and ${ }^{10} \mathrm{~B}$-containing drugs that are localized within malignant cells. ${ }^{3}$ The resulting nuclear reactions with the ${ }^{10} \mathrm{~B}$ nucleus ultimately lead to cell destruction in a very small volume due to the high kinetic energy (approximately $2.4 \mathrm{MeV}$ ) of the primary fission products $\left({ }^{7} \mathrm{Li}^{3+}\right.$ and $\left.{ }^{4} \mathrm{He}^{2+}\right)$. Microdosimetric calculations have shown that the radiobiological effectiveness of a capture reaction occurring in nucleus is much more effective than in cytoplasm. ${ }^{4,5}$ With these facts in mind, a variety of organic moieties, which are known to interact with chromosomal DNA, were tethered to boron-rich moieties such as $o$-carboranes. ${ }^{6}$ However, to date very few metal complexes have been tried as a carrier group to deliver the boron-rich compounds near to chromosomal DNA. ${ }^{7,8}$ cisDiamminedichloroplatinum(II) (cisplatin) is known to show its antitumor effects by binding to DNA of tumor cells in a covalent manner and blocking a cell proliferation. ${ }^{9}$ Recently, Rendina et al. prepared mono- and dinuclear platinum(II)amine complexes containing closo-1,2-carborane ${ }^{10}$ or $1,7-{ }^{6}$ or 1,12 -isomers ${ }^{11}$ and reported their in vitro DNA-binding properties such as cisplatin analogs. ${ }^{6}$

Herein we report the preparation and characterization of the first stable platinum(II) complex containing $o$-carboranelinked bipyridine as a potential carrier group to chromosomal DNA. Carborane-linked bipyridine compound, 4,4'(3-(1-methyl-1,2-dicarba-closo-dodecaborane-1-yl)carbpropoxy)-2,2'-bipyridine (3) was prepared by the reaction of dicesium 2,2'-bipyridine-4,4'-dicarboxylate (1) and 1methyl-2-(3-chloropropyl)-o-carborane (2). (Scheme 1) 2,2'Bipyridine-4,4'-dicarboxylic acid was converted to its cesium salt (1) by neutralization of the acids with aqueous $\mathrm{Cs}_{2} \mathrm{CO}_{3}$ in quantitative yield. 3-Chloropropyl-o-carborane (2) was synthesized by nucleophilic substitution of bromide ion of 1-bromo-3-chloropropane with n-butyllithium-treated 1 -Me- $O$-carborane at $-78{ }^{\circ} \mathrm{C}$. The esterifiacation reaction between cesium salt of carboxylic acid and alkyl halide proceeded very slowly (3 days) at $110{ }^{\circ} \mathrm{C}$ in DMF, presumably due to very low solubility of dicesium 2,2'bipyridyl-4,4'-dicarboxylate in DMF solvent. The crude product 3 was recrystallized from $\mathrm{THF} / \mathrm{Et}_{2} \mathrm{O}$ and fully characterized by ${ }^{1} \mathrm{H},{ }^{13} \mathrm{C}$ and ${ }^{11} \mathrm{~B}$ NMR..${ }^{12}$

Platinum complex of $o$-carborane-linked bipyridine $\operatorname{Pt}(3) \mathrm{Cl}_{2}$ was prepared by the displacement of the weakly bound benzonitrile ligands in cis- $\left[\mathrm{Pt}(\mathrm{PhCN})_{2} \mathrm{Cl}_{2}\right]$ in THF solution by 4,4'-(3-(1-methyl-1,2-dicarba-closo-dodecaborane-1-yl)carbpropoxy)-2,2'-bipyridine (3). (Scheme 1) Without reflux heating, the complexation proceeded very sluggish, which could be ascribed to a high activation energy barrier for complexation in which the ligand acts as a
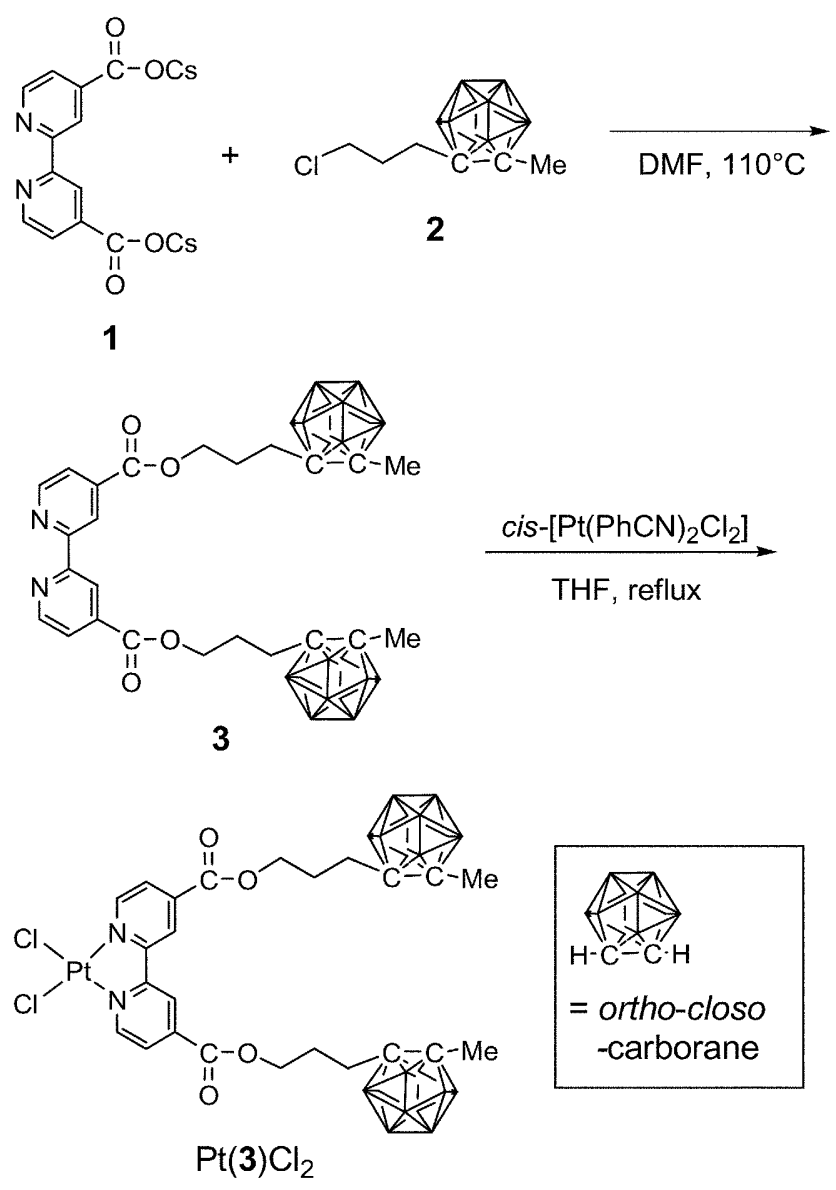

Scheme 1 


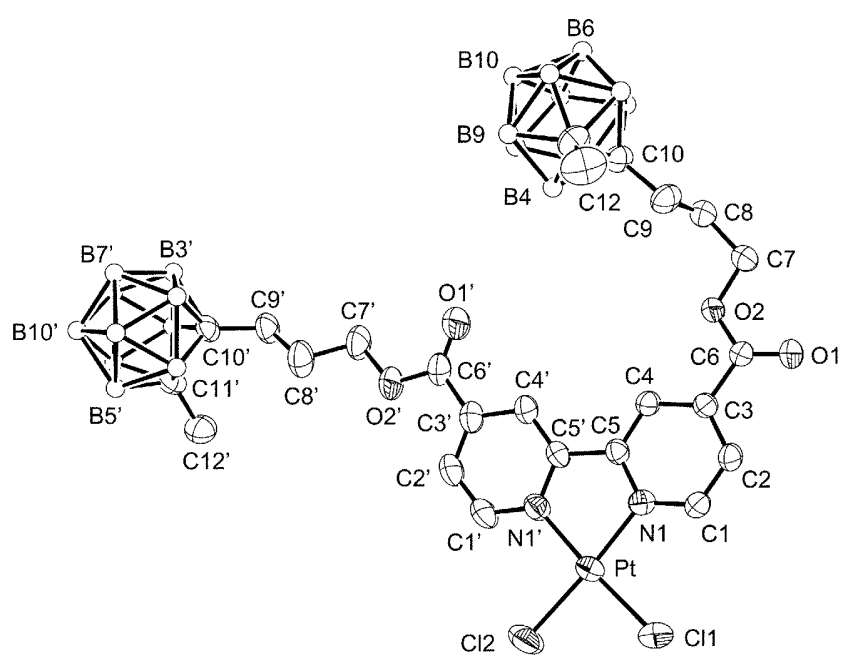

Figure 1. ORTEP drawing of $\operatorname{Pt}(\mathbf{3}) \mathrm{Cl}_{2} \cdot \mathrm{DMF}$ (3.DMF) showing the atom-numbering scheme. DMF molecule was omitted for clarity.

chelating ligand via two $\mathrm{N}$ atoms. The significant steric hindrance seems to be caused by the introduction of bulky boron cluster on each 4-position of pyridine ring, resulting in the flipping away of two nitrogen atoms in bipyridine. $\mathrm{Pt}(\mathbf{3}) \mathrm{Cl}_{2}$ was fully characterized by various spectroscopic methods. ${ }^{13}{ }^{195} \mathrm{Pt}$ NMR spectrum showed single peak in the ranges observed for $\mathrm{Pt}(\mathrm{II})$ complexes with bipyridine derivatives. ${ }^{14,15}$ In contrast to previously reported platinum(II) complexes containing 1-aminoalkyl-1,2-carborane ligands, ${ }^{10}$ $\operatorname{Pt}(\mathbf{3}) \mathrm{Cl}_{2}$ exhibited excellent stability both in solution and in the solid state. Presumably due to the high lipophilicity of incorporated carborane cages in $\mathrm{Pt}(\mathrm{II})$ complex, $\mathrm{Pt}(\mathbf{3}) \mathrm{Cl}_{2}$ showed limited water solubility.

Molecular structure of $\mathrm{Pt}(\mathbf{3}) \mathrm{Cl}_{2} \cdot \mathrm{DMF}$ was determined by $\mathrm{X}$-ray diffraction ${ }^{16}$ and an ORTEP view of $\mathrm{Pt}(\mathbf{3}) \mathrm{Cl}_{2} \cdot \mathrm{DMF}$ was presented in Figure 1. The Pt(II) complex possesses a square planar coordination geometry with the two chloride atoms trans to the diimine $\mathrm{N}$ atoms. ${ }^{17}$ The Pt-N distances of 2.007 and $2.011 \AA$ and N-Pt-N bond angle of $80.6^{\circ}$ agree well with values found for other $\mathrm{Pt}(\mathrm{II})$ diimine complexes. ${ }^{18,19}$ The Pt-Cl bond distance $(2.288$ and $2.290 \AA)$ and $\mathrm{Cl}-\mathrm{Pt}-\mathrm{Cl}$ bond angle $\left(88.77^{\circ}\right)$ are very similar to the corresponding values of $\left[\mathrm{Pt}\left(\mathrm{bu}_{2} \mathrm{bpy}\right) \mathrm{Cl}_{2}\right] \cdot{ }^{18}$ Except for the substituents at 4,4'-positions of bipyridine, the molecule is remarkably planar. The average deviation from planarity of $\mathrm{PtN}_{2} \mathrm{Cl}_{2}$ is only $0.02 \AA$. The angle between the least-squares planes of the two pyridine subunits is only $4.0^{\circ}$ and both two average pyridine rings form dihedral angles of $5.0^{\circ}$ with the $\mathrm{PtN}_{2} \mathrm{Cl}_{2}$ coordination plane. The bond lengths and angles of $o$-carboranes are consistent with other corresponding values and are unremarkable..$^{7,20,21}$

In conclusion, we prepared the first platinum(II) complex of carborane-containing bipyridine for potential use in boron neutron capture therapy. The complex was fully characterized by various spectroscopic methods including ${ }^{195} \mathrm{Pt}$ NMR spectroscopy and was found to be very stable both to air and to moisture. X-ray crystallographic structure determination revealed that the complex possesses square planar coordi- nation geometry and the molecule is remarkably planar.

Acknowledgment. The authors gratefully acknowledge financial supports from the CMDS and the BK 21 Project.

Supplementary Material Available. Crystallographic data for the structure reported here have been deposited with the Cambridge Crystallographic Data Centre (Deposition No. CCDC 261762). These data can be obtained free of charge via www.ccdc.cam.ac.uk/data_request/cif, or by emailingdata_request@ccdc.cam.ac.uk, or by contacting The Cambridge Crystallographic Data Centre, 12, Union Road, Cambridge CB2 1EZ, UK; fax: +44 1223336033.

\section{References}

1. Hawthorne, M. F. Angew. Chem., Int. Ed. Engl. 1993, 32, 950.

2. Soloway, A. H.; Tjarks, W.; Barnum, B. A.; Rong, F.-G.; Barth, R. F.; Codogni, I. M.; Wilson, J. G. Chem. Rev. 1998, 98, 1515.

3. Mehta, S. C.; Lu, D. R. Pharm. Res. 1996, 13, 344.

4. Gabel, D.; Foster, S.; Fairchild, R. G. Rad. Res. 1987, 111, 14.

5. Kobayashi, T.; Kanda, K. Rad. Res. 1982, 91, 77.

6. Woodhouse, S. L.; Rendina, L. M. Chem. Commun. 2001, 2464.

7. Todd, J. A.; Caiazza, D.; Tiekink, E. R. T.; Rendina, L. M. Inorg. Chim. Acta 2003, 352, 208.

8. Todd, J. A.; Rendina, L. M. Inorg. Chem. 2002, 41, 3331.

9. Hambley, T. W. Coord. Chem. Rev. 1997, 166, 181.

10. Todd, J. A.; Rendina, L. M. Inorg. Chem. Commun. 2004, 7, 289.

11. Woodhouse, S. L.; Rendina, L. M. Dalton Trans. 2004, 3669.

12. Compound 3: $29 \%$ yield. ${ }^{1} \mathrm{H}$ NMR (300 MHz, DMF- $\left.d_{7}, 363 \mathrm{~K}\right): \delta$ $8.99(\mathrm{~d}, J=4.9 \mathrm{~Hz}, 2 \mathrm{H}), 8.95(\mathrm{~d}, J=1.5 \mathrm{~Hz}, 2 \mathrm{H}), 8.01(\mathrm{dd}, J=$ $4.9,1.5 \mathrm{~Hz}, 2 \mathrm{H}), 4.49(\mathrm{t}, J=6.2 \mathrm{~Hz}, 4 \mathrm{H}), 2.67(\mathrm{~m}, 4 \mathrm{H}), 2.23(\mathrm{~s}$, $6 \mathrm{H}), 2.13(\mathrm{~m}, 4 \mathrm{H}) .{ }^{13} \mathrm{C}\left\{{ }^{1} \mathrm{H}\right\}$ NMR (75 MHz, DMF- $\left.d_{7}, 363 \mathrm{~K}\right): \delta$ 165.3, 156.9, 151.1, 139.5, 123.7, 120.3, 79.7, 77.2, 65.1, 32.1, 29.2, 23.1. ${ }^{11} \mathrm{~B}\left\{{ }^{1} \mathrm{H}\right\}$ NMR (96.3 MHz, DMF, $\left.363 \mathrm{~K}\right): \delta-5.4,-6.5$, -11.1 .

13. $\mathrm{Pt}(3) \mathrm{Cl}_{2}: 81 \%$ yield. ${ }^{1} \mathrm{H}$ NMR (400 MHz, DMF- $d_{7}$ ): $\delta 9.82(\mathrm{~d}, J=$ $6.1 \mathrm{~Hz}, 2 \mathrm{H}), 9.15(\mathrm{~d}, J=1.8 \mathrm{~Hz}, 2 \mathrm{H}), 8.37(\mathrm{dd}, J=6.1,1.8 \mathrm{~Hz}$, $2 \mathrm{H}), 4.54(\mathrm{t}, J=6.3 \mathrm{~Hz}, 4 \mathrm{H}), 2.69(\mathrm{~m}, 4 \mathrm{H}), 2.24(\mathrm{~s}, 6 \mathrm{H}), 2.15(\mathrm{~m}$, $4 \mathrm{H}) .{ }^{13} \mathrm{C}\left\{{ }^{1} \mathrm{H}\right\}$ NMR $\left(100 \mathrm{MHz}, \mathrm{DMF}-d_{7}\right): \delta 163.9,158.2,150.3$, 141.2, 128.1, 124.8, 79.6, 77.3, 66.0, 31.9, 29.3, 23.2. ${ }^{11} \mathrm{~B}\left\{{ }^{1} \mathrm{H}\right\}$ NMR (96.3 MHz, DMF): $\delta-6.5,-11.1 .{ }^{195} \mathrm{Pt}$ NMR $(64.5 \mathrm{MHz}$, DMF): $\delta$-2286. IR $\left(\mathrm{KBr}, \mathrm{cm}^{-1}\right): 3083 \mathrm{w}, 2972 \mathrm{w}, 2580 \mathrm{vs}, 1737 \mathrm{~s}$, $1645 \mathrm{~s}, 1413 \mathrm{~m}, 1317 \mathrm{~m}, 1253 \mathrm{~s}, 1133 \mathrm{~m}, 1018 \mathrm{~m}, 891 \mathrm{w}, 762 \mathrm{~m}$.

14. Yoo, J.; Kim, J.-H.; Sohn, Y. S.; Do, Y. Inorg. Chim. Acta 1997, $263,53$.

15. Yoo, J.; Sohn, Y. S.; Do, Y. J. Inorg. Biochem. 1999, 73, 187.

16. Crystal data for $\mathrm{Pt}(\mathbf{3}) \mathrm{Cl}_{2}$.DMF: $\mathrm{C}_{27} \mathrm{H}_{51} \mathrm{~B}_{20} \mathrm{Cl}_{2} \mathrm{~N}_{3} \mathrm{O}_{5} \mathrm{Pt}, M=979.90$, triclinic, space group $P \overline{\mathrm{I}}$ (No. 2), $a=11.490$ (3) $\AA$, $b=12.995(3)$ $\AA, c=16.211(2) \AA, \alpha=79.16(2)^{\circ}, \beta=87.56(2)^{\circ}, \gamma=68.03(2)^{\circ}, V$ $=2203.6(8) \AA^{3}, Z=2, d_{\text {calc }}=1.477 \mathrm{~g} / \mathrm{cm}^{3}, F(000)=972,7169$ unique, 523 parameters, $R_{1}=0.0365, w R_{2}=0.0920(6398, I>$ $2 \sigma(I)), \mathrm{GOF}=1.117$. Data were collected on an Enraf-Nonius CAD4TSB diffractometer using graphite-monochromated Mo-K $\alpha$ radiation. The structure was solved by Patterson method and Fourier methods and refined by full-matrix least squares based on $F^{2}$ using SHELXS 86 and SHELXL 93.

17. Lee, E. J.; Jun, M.-J.; Sohn, Y. S. Bull. Korean Chem. Soc. 1999, $20,1469$.

18. Achar, S.; Catalano, V. J. Polyhedron 1997, 16, 1555.

19. Paw, W.; Lachicotte, R. J.; Eisenberg, R. Inorg. Chem. 1998, 37, 4139.

20. Base, K.; Grinstaff, M. W. Inorg. Chem. 1998, 37, 1432.

21. Kim, S.-J.; Lee, S.; Kim, Y.; Ko, J.-J.; Kang, S. O. Bull. Korean Chem. Soc. 1995, 16, 634. 